\title{
Biomonitoring of Mercury Contamination in Poland Based on Its Concentration in Scots Pine (Pinus sylvestris L.) Foliage
}

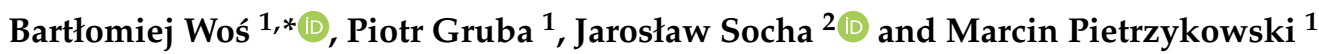 \\ 1 Department of Ecology and Silviculture, Faculty of Forestry, University of Agriculture in Krakow, \\ al. 29 Listopada 46, 31-425 Krakow, Poland; piotr.gruba@urk.edu.pl (P.G.); \\ marcin.pietrzykowski@ur.krakow.pl (M.P.) \\ 2 Department of Forest Resources Management, Faculty of Forestry, University of Agriculture in Krakow, \\ al. 29 Listopada 46, 31-425 Krakow, Poland; jaroslaw.socha@urk.edu.pl \\ * Correspondence: b.wos@ur.krakow.pl
}

Citation: Woś, B.; Gruba, P.; Socha, J.; Pietrzykowski, M. Biomonitoring of Mercury Contamination in Poland Based on Its Concentration in Scots Pine (Pinus sylvestris L.) Foliage. Int. J. Environ. Res. Public Health 2021, 18, 10366. https://doi.org/10.3390/ ijerph181910366

Academic Editor: Paul B. Tchounwou

Received: 14 May 2021

Accepted: 30 September 2021

Published: 1 October 2021

Publisher's Note: MDPI stays neutral with regard to jurisdictional claims in published maps and institutional affiliations.

Copyright: (C) 2021 by the authors Licensee MDPI, Basel, Switzerland. This article is an open access article distributed under the terms and conditions of the Creative Commons Attribution (CC BY) license (https:// creativecommons.org/licenses/by/ $4.0 /)$

\begin{abstract}
This work evaluates current mercury $(\mathrm{Hg})$ contamination in Poland, represented by the $\mathrm{Hg}$ concentrations in Scots pine foliage. Samples were collected over 295 investigation plots in monitoring grids throughout Poland, from pines aged between 12 and 147 years. Analyses were conducted with consideration of bioclimatic factors and soil properties. Concentrations in the pine foliage did not exceed the values characteristic of an ecosystem unaffected by industrial pollution, ranging from 0.0032 to $0.0252 \mathrm{mg} \mathrm{kg}^{-1}$ dry mass. However, pine stands located in western and central Poland, and in the northwest near the Baltic Sea, exhibited higher Hg concentrations in foliage than in eastern regions. Hg content in foliage depends on the mean temperature of the driest quarter, as well as on $\mathrm{Hg}$ content in soils. This indicates that the periods of drought observed in recent years in Poland may affect $\mathrm{Hg}$ concentrations in pine foliage.
\end{abstract}

Keywords: trace elements; mercury; pollution; biomonitoring; Scots pine

\section{Introduction}

Mercury $(\mathrm{Hg})$ pollution is one of the most serious environmental problems, mainly due to its toxicity to environmental and human health [1]. Long-term $\mathrm{Hg}$ exposure can cause brain damage in humans, leading to metabolic disturbances, psychopathological symptoms, and sensory impairment [2].

$\mathrm{Hg}$ is emitted from natural sources-such as volcanic eruptions, ocean evaporation, geothermal processes, and weathering of minerals containing $\mathrm{Hg}[3,4]$ —or as a result of re-emission of $\mathrm{Hg}$ accumulated from preceding anthropogenic emissions [5,6]. However, the majority of $\mathrm{Hg}$ deposited in the environment comes from anthropogenic emissions [7]. In earlier years, it was estimated that as much as $70-80 \%$ of total $\mathrm{Hg}$ emissions into the environment were anthropogenic in origin [8]. As a result of international agreements, including the Minamata Convention on Mercury [5], the share of $\mathrm{Hg}$ deposition from anthropogenic sources is decreasing. Estimates in the year 2000 indicated that anthropogenic $\mathrm{Hg}$ emissions on a global scale are similar to $\mathrm{Hg}$ emissions from natural sources. Fossil fuel combustion-mainly coal — was the principal global contributor among anthropogenic sources, accounting for some $60 \%$ of $\mathrm{Hg}$ emissions to the atmosphere [9]. Currently, it is estimated that anthropogenic emissions account for $\sim 30 \%$ of total global $\mathrm{Hg}$ emissions to the atmosphere, while $70 \%$ are from natural sources (primary $\mathrm{Hg}$ emissions and re-emissions) $[7,10]$. However, the global reservoir of atmospheric $\mathrm{Hg}$ has increased to 2-5 times above pre-industrial levels [11].

Poland's Hg emissions are among the highest in Europe [12], due to the prominence of coal in the country's energy mix [13]. The annual $\mathrm{Hg}$ emissions throughout Poland were estimated at $10 \mathrm{Mg}$ in 2015 (about $0.03 \mathrm{~kg}$ per square kilometer), and they have remained nearly the same since 2000 [14]. In recent years, however, there has been a gradual decrease 
in Hg emissions which, in 2018, fell below 9 Mg. Poland's share of overall European emissions in 2018 was $17.2 \%$ (a decrease of 1.2 percentage points compared to 2010) [15]. About half of Poland's total $\mathrm{Hg}$ emissions were due to fossil fuel combustion for electricity, with the other main sources being processes in the cement, chemical, and metallurgical industries $[9,10]$.

Due to the threats posed to ecosystems and human health, both local and global $\mathrm{Hg}$ monitoring are critical to meeting the international $\mathrm{Hg}$ treaty, as well as to most national policies [6]. One measure of $\mathrm{Hg}$ pollution and its spatial distribution is the biomonitoring and determination of $\mathrm{Hg}$ concentrations in plant tissues [16]. Biomonitoring can also inform environmental risk assessments by measuring or estimating the concentration of a pollutant in the environment, and then estimating stress on humans and the environment due to pollution exposure [17].

The $\mathrm{Hg}$ in plant foliage comes mainly from the air, because $\mathrm{Hg}$ uptake from the soil tends to be accumulated in the belowground biomass (i.e., the roots), and the translocation of this element above ground is poor $[18,19]$. For these reasons, the $\mathrm{Hg}$ concentration in the aboveground biomass of vascular plants is commonly used to assess air $\mathrm{Hg}$ pollution $[17,20]$. Climatic conditions such as temperature, light, wind, turbulence, and humidity affect the deposition and uptake of $\mathrm{Hg}$ by plants from the atmosphere [17]. However, one further mechanism of interest is foliar uptake of $\mathrm{Hg}^{0}$ volatilized from the soil. Soils have different potentials for $\mathrm{Hg}$ storage, depending on texture, soil organic matter content, and $\mathrm{pH}[21,22]$, so different soil potentials for $\mathrm{Hg}$ storage may affect $\mathrm{Hg}$ re-emission and volatilized values.

Scots pine (Pinus sylvestris L.) is one of the most commonly used tree species in biomonitoring in temperate climate zones, due to its wide geographical range, broad ecological amplitude, and high tolerance to pollution. A good indicator of environmental pollution is the pollutant content in foliage [23-25]. However, the use of pine needles to monitor mercury pollution has mainly been conducted on a regional scale-for example, in highly polluted regions $[25,26]$. The aim of this work is to determine $\mathrm{Hg}$ concentrations in Scots pine foliage in Poland in order to support the current biomonitoring of air pollution in Central and Eastern Europe. The following research hypotheses were tested: (1) Hg concentration in pine foliage overlaps with the spatial distribution of $\mathrm{Hg}$ emission and deposition in Poland, and is elevated in heavily urbanized regions; (2) $\mathrm{Hg}$ concentration in foliage depends on bioclimatic factors; and (3) $\mathrm{Hg}$ concentration in foliage depends on soil properties and parent rock material.

\section{Study Sites}

\subsection{Location}

The research was carried out at 295 permanent monitoring plots established throughout Poland (Figure 1). The plots were established in pure pine stands aged between 12 and 147 years (mean: 67 years). The area of the plot was selected so that each plot had a minimum of 30 trees, and ranged from 0.02 ha in the youngest (11-20 years old) to 0.10 ha in the oldest stands ( $>80$ years old) [27,28]. The distribution of research plots resulted from the diversity of habitat conditions, which is associated with the tree species compositions of stands. Scots pine in its natural range in Poland is mainly associated with lowland habitats [29]. 


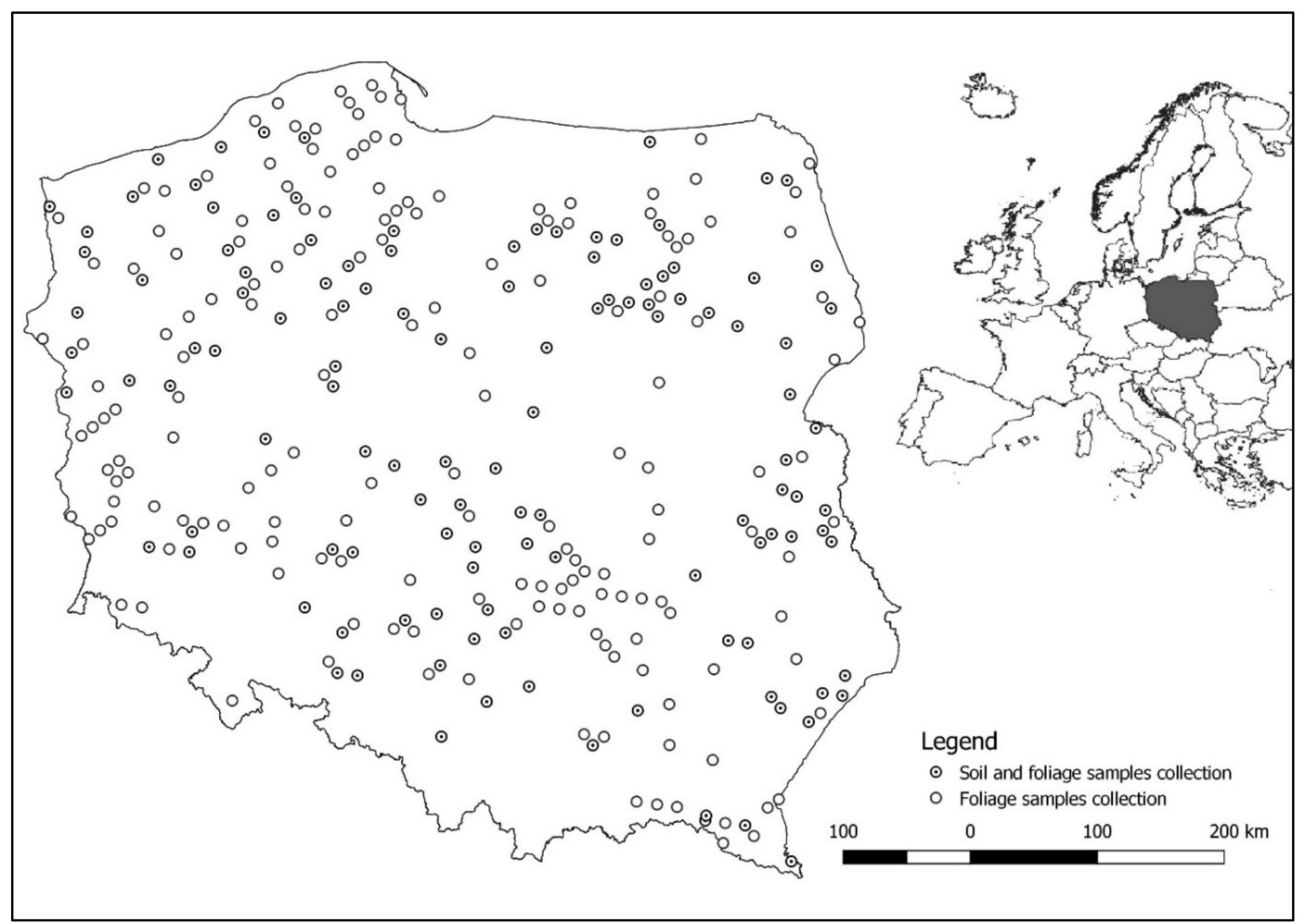

Figure 1. Location of monitoring plots for sampling of soil and Scots pine foliage.

\subsection{Climate Characteristics}

To characterize climate conditions, we estimated 19 bioclimatic variables for each plot using the WorldClim database [30]. The annual mean temperature (BIO1) for the research plots was $\sim 7.6^{\circ} \mathrm{C}$ (range from 5.5 to $9.1^{\circ} \mathrm{C}$ ). Temperatures ranged from a maximum of $23.1^{\circ} \mathrm{C}$ in the warmest month (BIO5) to a minimum of $6.9^{\circ} \mathrm{C}$ in the coldest (BIO6). Annual precipitation (BIO12) was $594 \mathrm{~mm}$ (from 499 to $779 \mathrm{~mm}$ ). Precipitation in the wettest month (BIO13) was $80 \mathrm{~mm}$ and, for the driest month, $28 \mathrm{~mm}$ (BIO14; Table 1).

Growth and climate conditions were also described using topography. As an indirect measure of regional climate variations, we used elevation above sea level, estimated using a digital elevation model (DEM) with $25 \mathrm{~m}$ resolution and vertical accuracy (random mean square error) of $+/-7 \mathrm{~m}$. Local microclimate was characterized by aspect and slope position. The local topographic wetness index (TWI) and slope position were derived from the DEM data [31]. Elevation above sea level was from 14.1 to $653.6 \mathrm{~m}$. The slopes ranged from $0.0^{\circ}$ to $14.2^{\circ}$. The research plots were characterized by a TWI between 5.40 and 16.19 (Table 2). 
Table 1. Bioclimatic variables on research plots ( $n=195$; source of data: global climate and weather data, www.worldclim.org).

\begin{tabular}{|c|c|c|c|c|c|c|c|c|c|c|c|c|c|c|c|c|c|c|c|}
\hline & \multicolumn{19}{|c|}{ Bioclimatic Variables ${ }^{1}$} \\
\hline & $\begin{array}{c}\text { BIO1 } \\
\left({ }^{\circ} \mathrm{C}\right)\end{array}$ & $\begin{array}{c}\mathrm{BIO} 2 \\
\left({ }^{\circ} \mathrm{C}\right)\end{array}$ & $\begin{array}{c}\text { BIO3 } \\
(\%)\end{array}$ & $\begin{array}{c}\mathrm{BIO} 4 \\
\left({ }^{\circ} \mathrm{C}\right)\end{array}$ & $\begin{array}{c}\text { BIO5 } \\
\left({ }^{\circ} \mathrm{C}\right)\end{array}$ & $\begin{array}{l}\text { BIO6 } \\
\left({ }^{\circ} \mathrm{C}\right)\end{array}$ & $\begin{array}{c}\text { BIO7 } \\
\left({ }^{\circ} \mathrm{C}\right)\end{array}$ & $\begin{array}{c}\text { BIO8 } \\
\left({ }^{\circ} \mathrm{C}\right)\end{array}$ & $\begin{array}{c}\text { BIO9 } \\
\left({ }^{\circ} \mathrm{C}\right)\end{array}$ & $\begin{array}{c}\text { BIO10 } \\
\left({ }^{\circ} \mathrm{C}\right)\end{array}$ & $\begin{array}{c}\text { BIO11 } \\
\left({ }^{\circ} \mathrm{C}\right)\end{array}$ & $\begin{array}{c}\text { BIO12 } \\
(\mathrm{mm})\end{array}$ & $\begin{array}{c}\text { BIO13 } \\
(\mathrm{mm})\end{array}$ & $\begin{array}{c}\text { BIO14 } \\
(\mathrm{mm})\end{array}$ & $\begin{array}{c}\text { BIO15 } \\
(\%)\end{array}$ & $\begin{array}{l}\text { BIO16 } \\
(\mathrm{mm})\end{array}$ & $\begin{array}{c}\text { BIO17 } \\
\text { (mm) }\end{array}$ & $\begin{array}{l}\text { BIO18 } \\
(\mathrm{mm})\end{array}$ & $\begin{array}{l}\text { BIO19 } \\
\text { (mm) }\end{array}$ \\
\hline Mean & 7.6 & 8.0 & 26.2 & 7831 & 23.1 & -6.9 & 30.1 & 17.1 & -1.1 & 17.2 & -3.0 & 594 & 80 & 28 & 34.0 & 223.0 & 91.8 & 222.6 & 103.4 \\
\hline Max. & 9.1 & 9.1 & 31.0 & 8886 & 24.9 & -3.9 & 33.2 & 18.5 & 3.1 & 18.5 & -0.6 & 816 & 115 & 42 & 48 & 323 & 134 & 323 & 146 \\
\hline Max/Min & 1.7 & 1.5 & 1.3 & 1.3 & 1.3 & 0.4 & 1.3 & 1.3 & -0.7 & 1.3 & 0.1 & 1.6 & 1.8 & 2.1 & 2.2 & 1.8 & 1.9 & 1.8 & 1.9 \\
\hline
\end{tabular}

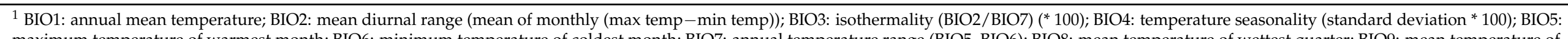

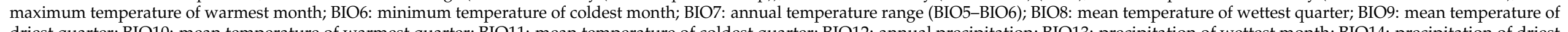

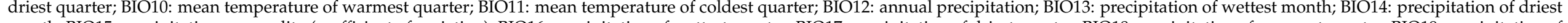

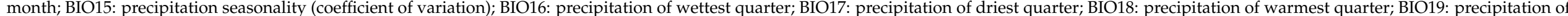
coldest quarter. 
Table 2. Elevation, slope, aspect, and local topographic wetness index (TWI) of the research plots.

\begin{tabular}{ccccc}
\hline & Elevation $(\mathbf{m})$ & Slope $\left({ }^{\circ}\right)$ & Aspect & TWI \\
\hline Mean & 167.6 & 2.4 & 199.21 & 8.33 \\
Min. & 14.1 & 0.0 & 2.01 & 5.40 \\
Max. & 653.6 & 14.2 & 359.82 & 16.19 \\
Max/Min & 46.5 & - & 179.22 & 3.00 \\
\hline
\end{tabular}

\subsection{Soil Characteristics}

The soils of the research plots were characterized by a diversity of parent rock types (GT: glacial tills; CS: claystones; MS: mudstones; L: loess; S: sands; SS: sandstones; LS: limestones; G: gravel) and groups (P: podzols; C: cambisols; M: mollisols; Le: leptosols; F: fluvisols; Lu: luvisols; BA: Brunic arenosols; CL: calcic leptosols) [28].

According to USDA soil classifications, heavy clay and sand were the most frequent soil types in the studied area. The $\mathrm{pH}$ of $\mathrm{H}_{2} \mathrm{O}$ in mineral layers $(0-10,10-40$, and $40-100 \mathrm{~cm})$ ranged from 3.5 to 8.7. Cation-exchange capacity (CEC) also showed a large variation, ranging from 0.76 to $60.77 \mathrm{cmol}(+) \mathrm{kg}^{-1}$. The carbon content in surface soil layers $(0-10 \mathrm{~cm})$ ranged from 0.3 to $47.7 \%$ [27,28,32]. The $\mathrm{Hg}$ content in soils was low, and within the typical range for unpolluted forest sites. The average $\mathrm{Hg}$ concentration in organic soil layers $(\mathrm{O})$ was $0.12 \mathrm{mg} \mathrm{kg}^{-1}$; in $0-10 \mathrm{~cm}$ layers was $0.02 \mathrm{mg} \mathrm{kg}^{-1}$; and in both the $10-40 \mathrm{~cm}$ and $40-100 \mathrm{~cm}$ layers was $0.01 \mathrm{mg} \mathrm{kg}^{-1}$ (Table 3) [28].

Table 3. Selected soil properties on research plots $[27,28,32]$.

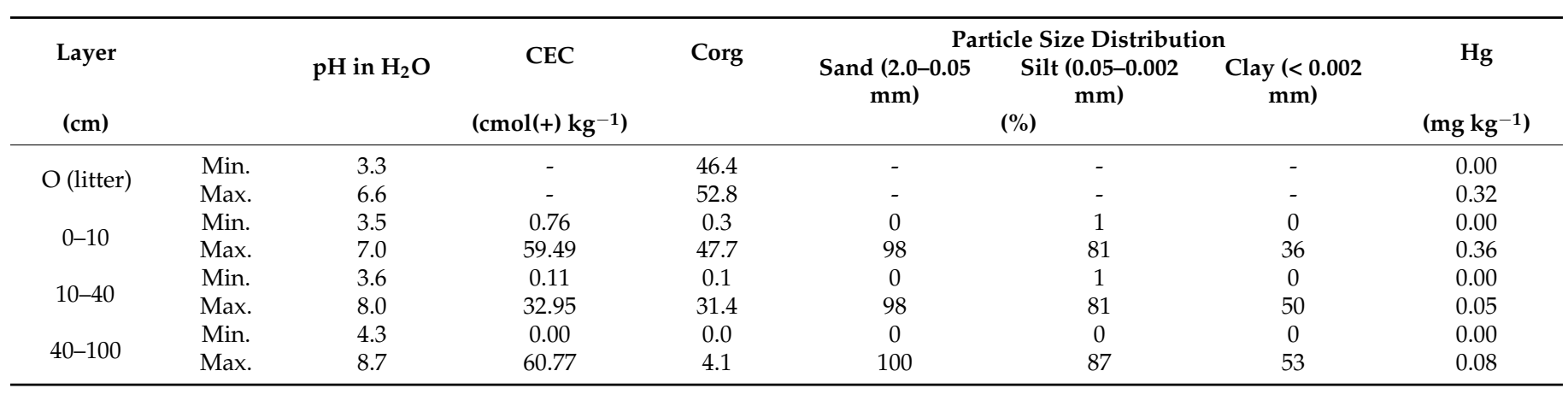

\section{Methods}

\subsection{Sampling and Laboratory Analyses}

On each site, one predominant tree (Kraft's first class) was selected. From the first branch located in the southwest exposure of the crown, 25 pairs of one-year-old needles were collected from the seventh whorl, counting from the apex. The samples were taken during two vegetation seasons in 2015 and 2016 (Figure 2).

In the laboratory, the needle samples were dried at $65{ }^{\circ} \mathrm{C}$, ground, and then the $\mathrm{Hg}$ content was determined using a DMA-80 Hg analyzer (Milestone), via drying and thermal decomposition [28]. Quality control was assured by calibration with standard European Reference Material (ERM) No CD281 (rye grass), with a certified Hg concentration of $0.0164 \mathrm{mg} \mathrm{kg}^{-1}$, and uncertainty of $0.0022 \mathrm{mg} \mathrm{kg}^{-1}$. The ERM analysis was performed at the beginning, and again at the end, of each experimental run (number of samples $=50$ ). The ERM and each sample were measured twice, with acceptable differences between the measurements $<10 \%$ (recoveries above $90 \%$ ). 


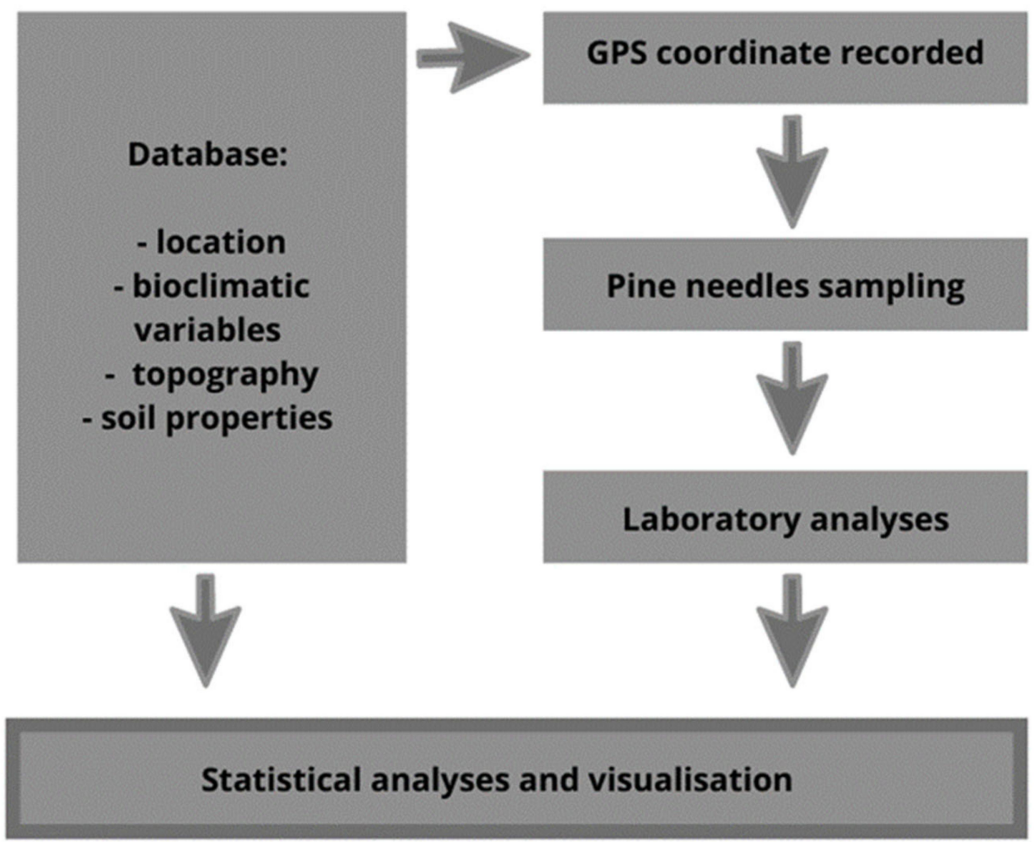

Figure 2. General scheme of the critical path for the data evaluation and study method.

\subsection{Statistical Analyses and Visualization}

The correlations between $\mathrm{Hg}$ concentration in pine foliage and bioclimatic variables, tree ages, and soil properties were analyzed using Pearson's correlation matrix and the multiple forward stepwise regression method. The correlation coefficient, with $\mathrm{n}=295$ samples, was calculated at probabilities $p=0.05$ and $p=0.01$. The significance of individual independent variables in multiple regression equations was tested using the $t$-test at a significance level of $p<0.05$. The statistical analyses were carried out using STATISTICA 13.1 software (StatSoft, Tulsa, OK, USA) (Figure 2).

Distribution of the investigated features was compared to the normal distribution using the Shapiro-Wilk test. The average values of analyzed characteristics of substrates were compared using ANOVA, preceded by Leven's variance homogeneity test. Significant differences between mean values of $\mathrm{Hg}$ concentrations in pine foliage from different areas in Poland were tested by post hoc RIR Tukey's multiple comparison procedure (at $p=0.05$ ). The spatial interpolation analysis for visualization of $\mathrm{Hg}$ concentration distribution in pine foliage in Poland was performed using the IDW module of QGIS 3.10 software (QGIS Development Team) (Figure 2).

\section{Results}

\subsection{Spatial Variation in $\mathrm{Hg}$ Concentration}

$\mathrm{Hg}$ concentrations in Scots pine foliage ranged from $0.0032 \mathrm{mg} \mathrm{kg}^{-1}$ to $0.0252 \mathrm{mg} \mathrm{kg}^{-1}$ (mean: $0.01 \mathrm{mg} \mathrm{kg}^{-1}$ ). Relatively higher $\mathrm{Hg}$ concentrations $\left(>0.01 \mathrm{mg} \mathrm{kg}^{-1}\right.$ ) were found in central (area I) and western Poland (area II). In addition, Hg concentrations in pine foliage exceeding $0.02 \mathrm{mg} \mathrm{kg}^{-1}$ were found in the vicinity of Zielona Góra (HS I), in the copper-exploitation region (HS II), and in the vicinity of Janów Lubelski (HS III) (Figure 3). 


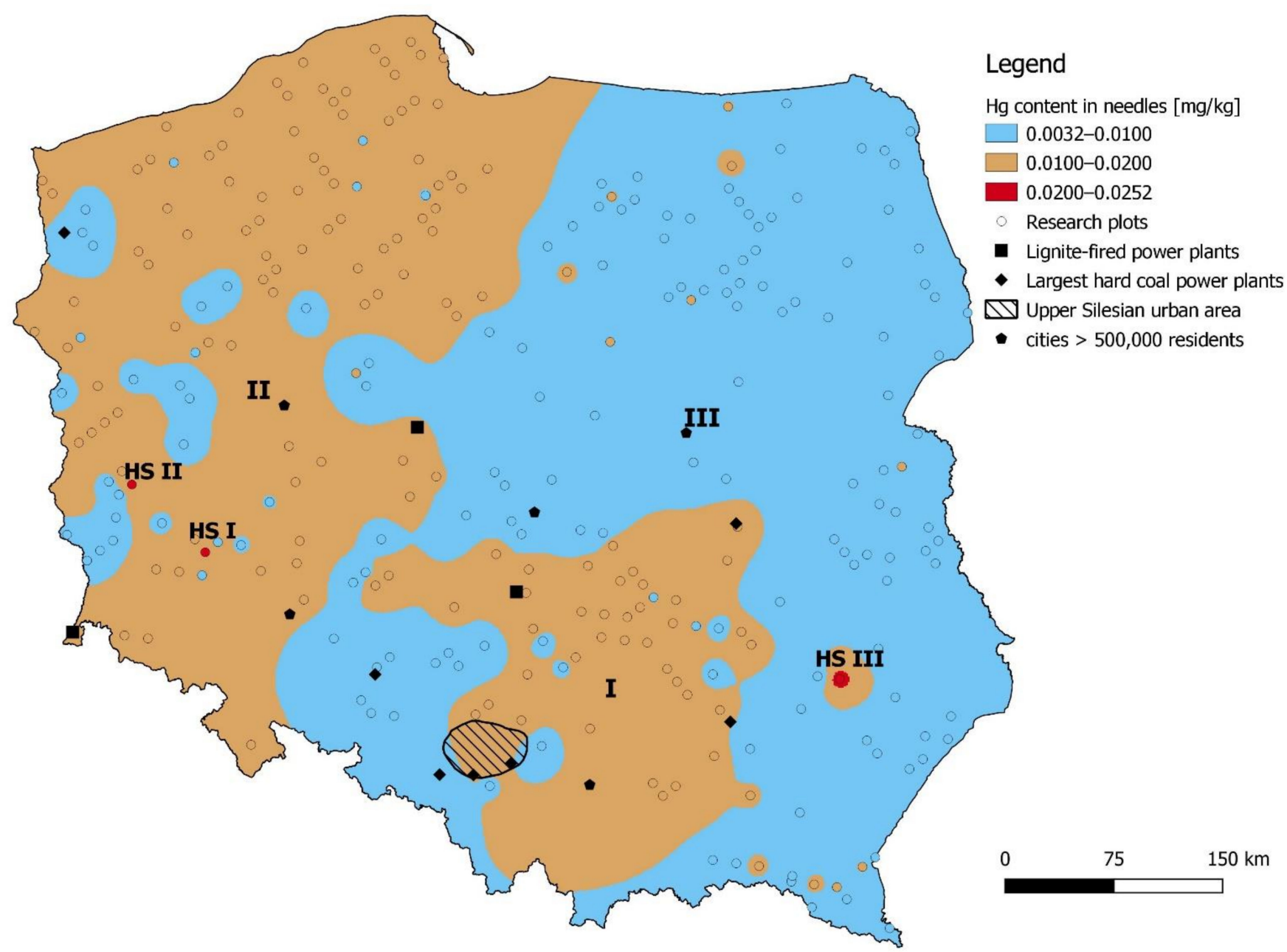

Figure 3. Spatial variation in $\mathrm{Hg}$ concentrations in pine foliage in Poland. Roman numerals indicate areas with different concentrations of $\mathrm{Hg}-\mathrm{I}$ : central Poland; II: western Poland; III: remaining area with lower $\mathrm{Hg}$ concentrations up to $0.01 \mathrm{mg} \mathrm{kg}{ }^{-1}$; HS I: hot spot I near Zielona Góra; HS II: hot spot II in the copper-exploitation region; HS III: hot spot III near Janów Lubelski.

We determined that the average $\mathrm{Hg}$ concentrations in areas I $\left(0.0128 \mathrm{mg} \mathrm{kg}^{-1}\right)$ and II $\left(0.0129 \mathrm{mg} \mathrm{kg}^{-1}\right)$ were significantly higher than in area III $\left(0.0075 \mathrm{mg} \mathrm{kg}^{-1}\right)$ (Table 4).

Table 4. Hg content in pine foliage in designated areas, on the basis of interpolation.

\begin{tabular}{ccccc}
\hline Area & \multicolumn{4}{c}{ Hg $\left(\mathbf{m g ~ k g}^{-\mathbf{1}}\right)$} \\
\hline & Mean & Min. & Max. & Max./Min. \\
\hline I & $0.0128 \pm 0.0020^{\mathrm{b} 1}$ & 0.0104 & 0.0180 & 1.73 \\
II & $0.0129 \pm 0.0024^{\mathrm{b}}$ & 0.0102 & 0.0180 & 1.77 \\
III & $0.0075 \pm 0.0026^{\mathrm{a}}$ & 0.0032 & 0.0099 & 3.09 \\
HS I & 0.0200 & - & - & - \\
HS II & 0.0208 & - & - & - \\
HS III & 0.0252 & - & - & -
\end{tabular}

${ }^{1}$ Mean \pm SD; within columns, means followed by different letters $\left({ }^{(a},{ }^{b}\right)$ are significantly different.

\subsection{Correlation between Hg Content in Pine Foliage, Bioclimatic Characteristics, and Soil Properties}

$\mathrm{Hg}$ content in pine foliage correlated positively with the mean temperature of the driest quarter (BIO9), annual precipitation (BIO12), precipitation in the driest month (BIO14), precipitation in the driest quarter (BIO17), and precipitation in the coldest quarter (BIO19). 
Foliar Hg content correlated negatively with mean diurnal range (BIO2), temperature seasonality (BIO4), maximum temperature of the warmest month (BIO5), annual temperature range (BIO7), mean temperature of the wettest quarter (BIO8), and precipitation seasonality (BIO15; Table 5).

Table 5. Pearson's correlation coefficients (r) between $\mathrm{Hg}$ content in pine foliage and bioclimatic variables.

\begin{tabular}{|c|c|c|c|c|c|c|c|c|c|c|c|c|c|c|c|c|c|c|c|}
\hline & BIO1 & $\mathrm{BIO} 2$ & BIO3 & BIO4 & BIO5 & BIO6 & BIO7 & BIO8 & BIO9 & BIO10 & BIO11 & BIO12 & BIO13 & BIO14 & BIO15 & BIO16 & BIO17 & BIO18 & BIO19 \\
\hline $\begin{array}{l}\mathrm{Hg}(\mathrm{mg} \\
\left.\mathrm{kg}^{-1}\right)\end{array}$ & 0.09 & -0.32 ** & -0.06 & -0.22 * & $\underset{* *}{-0.27}$ & 0.18 & $\underset{* *}{-0.29}$ & -0.20 * & $0.44 * *$ & -0.15 & 0.14 & $0.27^{* *}$ & 0.15 & 0.26 ** & $-0.19 *$ & 0.11 & $0.28 * *$ & 0.09 & $0.35 * *$ \\
\hline
\end{tabular}

For explanation of abbreviations for bioclimatic variables, see Table $1 .{ }^{*}$ : significant at $p<0.05 ;{ }^{* *}$ : significant at $p<0.01$.

No significant correlation was found between foliar $\mathrm{Hg}$ content and stand ages or soil properties (Hg content, $\mathrm{pH}$, texture, Corg, and CEC values). The lack of correlation with soil properties indicates that $\mathrm{Hg}$ content in pine needles does not depend on the soil parent material or geological strata, because different parent materials and geological strata have different properties. No significant correlation was found between foliar $\mathrm{Hg}$ content and elevation, aspect, slope position, or TWI index.

However, multiple regression analysis showed that foliar $\mathrm{Hg}$ content was related to the BIO9 and $\mathrm{Hg}$ content in the $0-100 \mathrm{~cm}$ soil layer. The determination coefficient explains $53 \%$ of the variation in foliar Hg content (Table 6; Equation (1)).

$\mathrm{Hg}$ in foliage $\left(\mathrm{mg} \mathrm{kg}^{-1}\right)=0.001 \times \mathrm{BIO} 9\left({ }^{\circ} \mathrm{C}\right)+0.157 \times \mathrm{Hg}_{0-100}\left(\mathrm{mg} \mathrm{kg}^{-1}\right)+0.01 \pm 0.002$

Table 6. Regression summary for $\mathrm{Hg}$ content in pine foliage $\left(\mathrm{mg} \mathrm{kg}^{-1}\right)$ as the dependent variable, and BIO9 $\left({ }^{\circ} \mathrm{C}\right)$ and $\mathrm{Hg}$ content $\left(\mathrm{mg} \mathrm{kg}^{-1}\right)$ in the $0-100 \mathrm{~cm}$ soil layer as independent variables; $\mathrm{R}^{2}$ adj. $=0.53 ; \mathrm{F}(2.64)=38.609 ; p<0.0000$.

\begin{tabular}{ccccc}
\hline Predictors & $\mathbf{b}$ & Standard Error of $\mathbf{b}$ & $\mathbf{t}(\mathbf{6 4 )}$ & $p$-Value \\
\hline Intercept & 0.01035 & 0.00044 & 23.54115 & 0.00000 \\
BIO9 & 0.00105 & 0.00014 & 7.729090 & 0.00000 \\
$\mathrm{Hg}_{0-100}$ & 0.15675 & 0.04025 & 3.894294 & 0.00024 \\
\hline
\end{tabular}

\section{Discussion}

\subsection{Hg Concentration and Spatial Distribution}

Although $\mathrm{Hg}$ content in Scots pine foliage in Poland did not exceed the values found in ecosystems outside industrial emission areas, this study examined the spatial variation in mercury content across the country. According to Gworek et al. [33], plants growing beyond the influence of high $\mathrm{Hg}$ emissions had less than $0.1 \mathrm{mg} \mathrm{kg}^{-1} \mathrm{Hg}$. Higher $\mathrm{Hg}$ concentrations in pine foliage were found in areas affected by industrial pollution, including in the catchment area $\sim 20 \mathrm{~km}$ from a lignite power plant in Spain (average $0.060 \mathrm{mg} \mathrm{kg}^{-1}$ ) [34], and the area around a chloralkali plant in the Czech Republic (from $0.0202 \mathrm{mg} \mathrm{kg}^{-1}$ in the plant's low-impact zone, up to $0.0615 \mathrm{mg} \mathrm{kg}^{-1}$ in the high-impact zone) [35]. In urban areas of the Krakow agglomeration, pine foliage exhibited a higher concentration of $\mathrm{Hg}$, ranging from 0.0286 to $0.0939 \mathrm{mg} \mathrm{kg}^{-1}$ [36]. However, $\mathrm{Hg}$ concentrations in pine foliage in areas affected by industrial pollution in Russia (in the basin of the Selenga River, within the boundaries of the Republic of Buryatia) ranged from 0.006 to $0.019 \mathrm{mg} \mathrm{kg}^{-1}$ [37], which fell within the range that we observed for Scots pine from Poland.

Spatial variation in $\mathrm{Hg}$ concentrations in Scots pine foliage is consistent with the estimates of spatial emission and deposition of $\mathrm{Hg}$ in Poland by Bartnicki et al. [14,38]. It can be assumed that a $\mathrm{Hg}$ concentration in pine foliage above $0.01 \mathrm{mg} \mathrm{kg}^{-1}$ overlaps with the emission levels estimated, for 2015 , above $10 \mathrm{~g} \mathrm{~km}^{-2}$ year $^{-1}$, and $\mathrm{Hg}$ deposition above $15 \mathrm{~g} \mathrm{~km}^{-2}$ year $^{-1}$ [14]. However, on the basis of $\mathrm{Hg}$ concentration in Scots pine foliage, no "hot spots" were found in the Upper Silesia region, which has a significantly higher emission rate, exceeding $100 \mathrm{~g} \mathrm{~km}^{-2}$ year ${ }^{-1}$, and $\mathrm{Hg}$ deposition above $30 \mathrm{~g} \mathrm{~km}^{-2}$ year $^{-1}$ [14,39]. There were also no higher $\mathrm{Hg}$ concentrations found in the vicinities of the largest cities 
( $>500,000$ inhabitants). The Hg concentrations in precipitation were often much higher at the urban sites compared to the research plots, which were all forest sites [40]. The absence of recorded hot spots in pine foliage may be due to the distribution of research plots, distance from emission sources, and scarcity of plots in this region. The spread of $\mathrm{Hg}$ from industrial sources varies depending on particle size and emission type. Larger particles fall nearby, while smaller particles are transported over long distances [17].

The highest $\mathrm{Hg}$ concentrations $\left(>0.02 \mathrm{mg} \mathrm{kg}^{-1}\right)$ in pine foliage occurred in three plots: The high $\mathrm{Hg}$ content in the first point (around Polkowice) resulted from the nearby Żelazny Most copper mining flotation waste landfill, $500 \mathrm{~m}$ to the south. The Żelazny Most flotation waste landfill is the largest of its kind in Europe, and has a negative impact on adjacent ecosystems through wind erosion and transport of pollutants-including trace elementsto both ground and surface waters [41]. In the case of the Legnica-Głogów Copper Mine District, it has already been reported by Barej et al. [42] that the $\mathrm{Hg}$ content in plant material (e.g., grasses and wheat cereals) exceeds those in unpolluted areas $\left(0.1 \mathrm{mg} \mathrm{kg}^{-1}\right.$ according to Gworek et al. [33]); however, the $\mathrm{Hg}$ concentrations found did not exceed the levels considered toxic, and the degree of contamination of plant material decreased over the 2002-2017 period [42,43]. The Hg concentrations in pine foliage in the vicinity of the flotation waste landfill in our study, although higher than those reported for the rest of Poland, also do not pose a threat to the environment. Similar values were given for the other two hot spots (around Zielona Góra and Janów Lubelski) located outside the areas with significant industrial emissions.

Interestingly, higher $\mathrm{Hg}$ concentrations in pine foliage were found in the vicinity of the Baltic Sea. Seas are an important sink for mercury deposition. Evaporation from the seas is one of the main factors of natural $\mathrm{Hg}$ emission to the environment, and also results from the re-emission of earlier depositions of anthropogenic origin. The sea is a $\mathrm{Hg}$ sink in winter, and an emission source during the growing season [44]. It was estimated in 2006 that total $\mathrm{Hg}$ emissions from the western and central parts of the Baltic Sea $\left(235,000 \mathrm{~km}^{2}\right.$, i.e., $\sim 60 \%$ of the sea area) were $4300 \pm 1600 \mathrm{~kg}$, and accounted for less than $5 \%$ of $\mathrm{Hg}$ emissions across Europe. According to Kuss and Schneider [45], the highest $\mathrm{Hg}$ emissions from the Baltic Sea were found to occur in the summer, and the lowest were measured in winter, which is associated with evaporation from the sea during summer. In the southern part of the Baltic Sea in 1997 and 1998, the mean annual Hg flux was estimated to be $9.5 \mu \mathrm{g} \mathrm{m}^{-2} \mathrm{yr}^{-1}$, and was higher in summer than in winter [46]. The decisive factor of $\mathrm{Hg}$ concentration in foliage should be considered the atmospheric $\mathrm{Hg}$ concentration. Although the Baltic Sea might act as an important $\mathrm{Hg}$ emission source, it does not exert a notable influence on atmospheric $\mathrm{Hg}$ concentrations [45]. The sea contributes humidity, and fog water (containing $\mathrm{Hg}$ ) deposition would be an important source of $\mathrm{Hg}$ in foliage [47]. For these reasons, the sea may favor $\mathrm{Hg}$ uptake by plants through its summer evaporation, which coincides with the period of most intensive plant growth.

\subsection{Impact of Bioclimatic Factors on $\mathrm{Hg}$ Concentration}

Atmospheric $\mathrm{Hg}$ reaches plants via both dry and wet deposition [48,49]. Precipitation absorbs and removes aerosols and pollutants from the atmosphere, and pollutants from precipitation can be more easily taken up by plants than pollutants from dry deposition [50]. The correlation of $\mathrm{Hg}$ content in foliage with precipitation from the driest month (BIO14) and quarter (BIO17) may be due to the concentration of ions and pollutants in precipitation being highest during the driest quarter, rather than the wettest [50]. The multiple regression analysis showed that $\mathrm{Hg}$ content in foliage depends on the mean temperature of the driest quarter (BIO9) and $\mathrm{Hg}$ content in the $0-100 \mathrm{~cm}$ soil layer. This may be due to foliar uptake of $\mathrm{Hg}^{0}$ volatilized from the soil. The $\mathrm{Hg}$ content in the air often increased with increasing temperature, which was likely caused by temperature-dependent surface emissions [51]. The study of Smith-Downey et al. [52] estimated that $56 \%$ of $\mathrm{Hg}$ deposited in terrestrial ecosystems is re-emitted. High temperature also promotes the partition of the particle with reactive $\mathrm{Hg}$ to the gaseous phase [53]. However, $\mathrm{Hg}$ resources accumulated during 
previous industrial emissions in the environment are needed for this process [18]. At very high temperatures, energy production (and, thus, the emission of pollutants to the atmosphere) increases as a result of its demand for cooling devices [54]. This can also indicate that the periods of drought with high temperatures, observed in recent years in Poland, may affect $\mathrm{Hg}$ re-emissions from ecosystem accumulations due to previous anthropogenic emissions.

\subsection{Impact of Soil Properties on $\mathrm{Hg}$ Concentration}

No significant correlations were noted between $\mathrm{Hg}$ concentration in pine foliage and soil properties, including $\mathrm{Hg}$ content in soils, confirming the limited translocation of this element from the roots to the aboveground biomass $[18,19]$. Such localization also indicates the usefulness of determining $\mathrm{Hg}$ concentrations in foliage for assessing air pollution [17]. Earlier studies on the spatial variation in $\mathrm{Hg}$ contamination in Polish soils showed that $\mathrm{Hg}$ concentration in soils is highest in southern Poland, which includes mainly mountainous and foothill areas [28,55]. The spatial variability in $\mathrm{Hg}$ content in Scots pine foliage, however, does not match these relationships. Plants take up $\mathrm{Hg}$ directly from water or soil through root systems, or from the air through stomata $[3,18]$. However, $\mathrm{Hg}$ taken up by plants from the soil tends to accumulate in the roots, and tends to be bound in sulfhydryl (-SH) groups [18].

\section{Conclusions}

$\mathrm{Hg}$ concentrations in Scots pine foliage did not exceed the values typical for ecosystems without industrial pollution, which are considered non-threatening. Spatial variation in $\mathrm{Hg}$ concentrations in Scots pine foliage did not overlap with spatial variation in $\mathrm{Hg}$ contamination in Polish soils, but was consistent with the estimates of $\mathrm{Hg}$ emission and deposition. It can be assumed that $\mathrm{Hg}$ concentrations in pine foliage above $0.01 \mathrm{mg} \mathrm{kg}^{-1}$ overlap with the emission levels estimated for 2015 above $10 \mathrm{~g} \mathrm{~km}^{-2}$ year $^{-1}$ and $\mathrm{Hg}$ deposition above $15 \mathrm{~g} \mathrm{~km}^{-2}$ year ${ }^{-1}$. However, based on $\mathrm{Hg}$ concentrations in Scots pine foliage, no "hot spots" were found in Upper Silesia, with its significantly higher emissions and the negative environmental effect of industrial pressure in recent years. $\mathrm{Hg}$ concentrations in pine foliage were positively correlated with the mean temperature of the driest quarter and annual precipitation. This correlation may indicate that Poland's recent droughts may affect $\mathrm{Hg}$ re-emissions from stock accumulated in ecosystems from previous anthropogenic emissions.

Author Contributions: Conceptualization, J.S. and M.P.; methodology, J.S., M.P., and P.G.; software, B.W.; data curation, B.W. and M.P.; writing—original draft preparation, B.W.; writing-review and editing, B.W., P.G., J.S., and M.P.; visualization, B.W.; project administration, J.S.; funding acquisition, J.S. All authors have read and agreed to the published version of the manuscript.

Funding: Research was financed by the Ministry of Science and Higher Education of the Republic of Poland, Department of Ecology and Silviculture, Faculty of Forestry. Data collection was supported by the project "Actual and potential site productivity in Poland for main forest forming tree species", financed by the General Directorate of State Forests agreement no. ER-2717-11/14, 15 April 2014 (Report data J. Socha, A. et al.: Actual and potential site productivity in Poland for main forest forming tree species. Final report of the project supported by State Forests National Forest Holding, 2017).

Institutional Review Board Statement: Not applicable.

Informed Consent Statement: Not applicable.

Conflicts of Interest: The authors declare no conflict of interest. 


\section{References}

1. Shahid, M.; Khalid, S.; Bibi, I.; Bundschuh, J.; Khan Niazi, N.; Dumat, C. A critical review of mercury speciation, bioavailability, toxicity and detoxification in soil-plant environment: Ecotoxicology and health risk assessment. Sci. Total Env. 2020, 711, 134749.

2. Gibb, H.; O'Leary, K.G. Mercury Exposure and Health Impacts among Individuals in the Artisanal and Small-Scale Gold Mining Community: A Comprehensive Review. Environ. Health Perspect. 2014, 122, 667-672. [CrossRef]

3. Kabata-Pendias, A. Trace Elements in Soils and Plants, 3rd ed.; CRC Press: Boca Raton, FL, USA, 2001.

4. Gustin, M.S.; Lindberg, S.E.; Weisberg, P.J. An update on the natural sources and sinks of atmospheric mercury. Appl. Geochem. 2008, 23, 482-493. [CrossRef]

5. Selin, H. Global Environmental Law and Treaty-Making on Hazardous Substances: The Minamata Convention and Mercury Abatement. Glob. Environ. Politics 2014, 14,1-19. [CrossRef]

6. Driscoll, C.T.; Mason, R.; Chan, H.M.; Jacob, D.J.; Pirrone, N. Mercury as a Global Pollutant: Sources, Pathways, and Effects. Environ. Sci. Technol. 2013, 47, 4967-4983. [CrossRef] [PubMed]

7. De Simone, F.; Gencarelli, C.N.; Hedgecock, I.; Pirrone, N. A Modeling Comparison of Mercury Deposition from Current Anthropogenic Mercury Emission Inventories. Environ. Sci. Technol. 2016, 50, 5154-5162. [CrossRef]

8. Mason, R.; Fitzgerald, W.; Morel, F. The biogeochemical cycling of elemental mercury: Anthropogenic influences. Geochim. Cosmochim. Acta 1994, 58, 3191-3198. [CrossRef]

9. Pacyna, E.G.; Pacyna, J.M.; Steenhuisen, F.; Wilson, S. Global anthropogenic mercury emission inventory for 2000. Atmospheric Environ. 2006, 40, 4048-4063. [CrossRef]

10. Pacyna, J.M.; Travnikov, O.; De Simone, F.; Hedgecock, I.M.; Sundseth, K.; Pacyna, E.G.; Steenhuisen, F.; Pirrone, N.; Munthe, J.; Kindbom, K. Current and future levels of mercury atmospheric pollution on a global scale. Atmos. Chem. Phys. Discuss. 2016, 16, 12495-12511. [CrossRef]

11. Boening, D.W. Ecological effects, transport, and fate of mercury: A general review. Chemosphere 2000, 40, 1335-1351. [CrossRef]

12. Glodek, A.; Pacyna, J.M. Mercury emission from coal-fired power plants in Poland. Atmos. Environ. 2009, 43, 5668-5673. [CrossRef]

13. Rybak, A. Poland's Energy Mix and Energy Security of the Country. World Sci. News 2019, 128, $402-415$.

14. Bartnicki, J.; Gusev, A.; Aas, W.; Gauss, M.; Jonson, J.E. Atmospheric Supply of Nitrogen, Cadmium, Mercury, Lead, and PCDD/Fs to the Baltic Sea in 2015; EMEP/MSC-W Technical Report 2/2017; EMEP Centres Joint Report for HELCOM: Oslo, Norway, 2017.

15. Inspection for Environmental Protection. Assessment of Air Pollution with Mercury at Regional Background Stations in Poland for State Environmental Monitoring; Chief Inspectorate Of Environmental Protection: Warsaw, Poland, 2020.

16. Chiarantini, L.; Rimondi, V.; Benvenuti, M.; Beutel, M.W.; Costagliola, P.; Gonnelli, C.; Lattanzi, P.; Paolieri, M. Black pine (Pinus nigra) barks as biomonitors of airborne mercury pollution. Sci. Total Environ. 2016, 569-570, 105-113. [CrossRef] [PubMed]

17. Lodenius, M. Use of plants for biomonitoring of airborne mercury in contaminated areas. Environ. Res. 2013, 125, 113-123. [CrossRef] [PubMed]

18. Patra, M.; Sharma, A. Mercury toxicity in plants. Bot. Rev. 2000, 66, 379-422. [CrossRef]

19. Woś, B.; Sroka, K.; Józefowska, A.; Pietrzykowski, M. Mercury Concentration in Technosols and Alder Tissue from a Plantation on a Combustion Waste Disposal Site. Water Air Soil Pollut. 2019, 230, 259. [CrossRef]

20. Du, B.; Zhou, J.; Zhou, L.; Fan, X.; Zhou, J. Mercury distribution in the foliage and soil profiles of a subtropical forest: Process for mercury retention in soils. J. Geochem. Explor. 2019, 205. [CrossRef]

21. Obrist, D.; Johnson, D.W.; Lindberg, S.E.; Luo, Y.; Hararuk, O.; Bracho, R.; Battles, J.J.; Dail, D.B.; Edmonds, R.L.; Monson, R.K.; et al. Mercury Distribution Across 14 U.S. Forests. Part I: Spatial Patterns of Concentrations in Biomass, Litter, and Soils. Environ. Sci. Technol. 2011, 45, 3974-3981. [CrossRef] [PubMed]

22. Richardson, J.B.; Friedland, A.J. Mercury in coniferous and deciduous upland forests in northern New England, USA: Implications of climate change. Biogeosciences 2015, 12, 6737-6749. [CrossRef]

23. Dmuchowski, W.; Bytnerowicz, A. Monitoring environmental pollution in Poland by chemical analysis of Scots pine (Pinus sylvestris L.) needles. Environ. Pollut. 1995, 87, 87-104. [CrossRef]

24. Aboal, J.; Fernández, J.; Carballeira, A. Oak leaves and pine needles as biomonitors of airborne trace elements pollution. Environ. Exp. Bot. 2004, 51, 215-225. [CrossRef]

25. Samecka-Cymerman, A.; Kosior, G.; Kempers, A. Comparison of the moss Pleurozium schreberi with needles and bark of Pinus sylvestris as biomonitors of pollution by industry in Stalowa Wola (southeast Poland). Ecotoxicol. Environ. Saf. 2006, 65, 108-117. [CrossRef]

26. Barquero, J.I.; Rojas, S.; Esbrí, J.M.; García-Noguero, E.M.; Higueras, P. Factors influencing mercury uptake by leaves of stone pine (Pinus pinea L.) in Almadén (Central Spain). Environ. Sci. Pollut. Res. 2017, 26, 3129-3137. [CrossRef]

27. Gruba, P.; Socha, J. Exploring the effects of dominant forest tree species, soil texture, altitude, and $\mathrm{pHH}_{2} \mathrm{O}$ on soil carbon stocks using generalized additive models. For. Ecol. Manag. 2019, 447, 105-114. [CrossRef]

28. Gruba, P.; Socha, J.; Pietrzykowski, M.; Pasichnyk, D. Tree species affects the concentration of total mercury (Hg) in forest soils: Evidence from a forest soil inventory in Poland. Sci. Total Environ. 2018, 647, 141-148. [CrossRef] [PubMed]

29. Giertych, M.; Mátyás, C. Genetics of Scots Pine, 1st ed.; Elsevier: Amsterdam, The Netherlands, 2013 ; Volume 3.

30. Fick, S.E.; Hijmans, R.J. WorldClim 2: New 1-km spatial resolution climate surfaces for global land areas. Int. J. Clim. 2017, 37, 4302-4315. [CrossRef] 
31. Socha, J.; Solberg, S.; Tymińska-Czabańska, L.; Tompalski, P.; Vallet, P. Height growth rate of Scots pine in Central Europe increased by 29\% between 1900 and 2000 due to changes in site productivity. For. Ecol. Manag. 2021, 490, 119102. [CrossRef]

32. Likus-Cieślik, J.; Socha, J.; Gruba, P.; Pietrzykowski, M. The current state of environmental pollution with sulfur dioxide $\left(\mathrm{SO}_{2}\right)$ in Poland (Central Europe) based on sulfur concentration in Scots pine (Pinus sylvestris L.) needles. Environ. Pollut. 2020, 258, 113559.

33. Gworek, B.; Dmuchowski, W.; Baczewska-Dabrowska, A.H. Mercury in the terrestrial environment: A review. Environ. Sci. Eur. 2020, 32, 1-19. [CrossRef]

34. Nóvoa-Muñoz, J.; Pontevedra-Pombal, X.; Cortizas, A.M.; Gayoso, E.G.-R. Mercury accumulation in upland acid forest ecosystems nearby a coal-fired power-plant in Southwest Europe (Galicia, NW Spain). Sci. Total Environ. 2008, 394, 303-312. [CrossRef] [PubMed]

35. Navrátil, T.; Šimeček, M.; Shanley, J.B.; Rohovec, J.; Hojdová, M.; Houska, J. The history of mercury pollution near the Spolana chlor-alkali plant (Neratovice, Czech Republic) as recorded by Scots pine tree rings and other bioindicators. Sci. Total Environ. 2017, 586, 1182-1192. [CrossRef]

36. Niemiec, M.; Arasimowicz, M. Mercury content in soil and needles of Scots Pine (Pinus silvestris L.) taken from the area of the Krakow agglomeration. Soil Sci. Ann. 2010, 61, 63-69.

37. Afanasieva, L.V.; Kashin, V.K.; Mikhailova, T.A.; Berezhnaya, N.S. Effect of the Industry-Related Air Pollution on the Accumulation of Heavy Metals in the Pine Needles in the Basin of the Selenga River. Chem. Sustain. Dev. 2007, 15, 25-31.

38. Bartnicki, J.; Gusev, A.; Aas, W.; Valiyaveetil, S. Atmospheric Supply of Nitrogen, Lead, Cadmium, Mercury and Dioxins/Furans to the Baltic Sea in 2010. EMEP/MSC-W Technical Report 2/2012; EMEP Centres Joint Report for HELCOM: Oslo, Norway, 2012.

39. Zyśk, J.; Roustan, Y.; Wyrwa, A. Modelling of the atmospheric dispersion of mercury emitted from the power sector in Poland. Atmos. Environ. 2015, 112, 246-256. [CrossRef]

40. Siudek, P.; Kurzyca, I.; Siepak, J. Atmospheric deposition of mercury in central Poland: Sources and seasonal trends. Atmos. Res. 2016, 170, 14-22. [CrossRef]

41. Lasocki, S.; Antoniuk, J.; Mościcki, J. Environmental Protection Problems in the Vicinity of the Żelazny Most Flotation Wastes Depository in Poland. J. Environ. Sci. Health Part A 2003, 38, 1435-1443. [CrossRef]

42. Barej, R.; Kwaśnicki, R.; Chojnacka, K.; Bolanowski, J.; Dobrzański, Z.; Pokorny, P. Mercury Content in Rural and Industrial Regions in Lower Silesia. Pol. J. Environ. Stud. 2009, 18, 547-552.

43. Dobrzański, Z.; Kołacz, R.; Czaban, S.; Bubel, F.; Malczewski, M.; Kupczynski, R.; Opalinski, S. Assessing Mercury Content in Plant and Animal Raw Materials in an Area Impacted by the Copper Industry. Pol. J. Environ. Stud. 2017, 26, 577-583. [CrossRef]

44. Bełdowska, M.; Saniewska, D.; Falkowska, L.; Lewandowska, A. Mercury in particulate matter over Polish zone of the southern Baltic Sea. Atmos. Environ. 2012, 46, 397-404. [CrossRef]

45. Kuss, J.; Schneider, B. Variability of the Gaseous Elemental Mercury Sea-Air Flux of the Baltic Sea. Environ. Sci. Technol. 2007, 41, 8018-8023. [CrossRef]

46. Wängberg, I.; Schmolke, S.; Schager, P.; Munthe, J.; Ebinghaus, R.; Iverfeldt, A. Estimates of air-sea exchange of mercury in the Baltic Sea. Atmos. Environ. 2001, 35, 5477-5484. [CrossRef]

47. Peckham, M.A.; Gustin, M.S.; Weisberg, P.J.; Weiss-Penzias, P. Results of a controlled field experiment to assess the use of tree tissue concentrations as bioindicators of air Hg. Biogeochemistry 2018, 142, 265-279. [CrossRef]

48. Lodenius, M. Dry and wet deposition of mercury near a chlor-alkali plant. Sci. Total Environ. 1998, 213, 53-56. [CrossRef]

49. Miller, E.K.; Van Arsdale, A.; Keeler, G.J.; Chalmers, A.; Poissant, L.; Kamman, N.C.; Brulotte, R. Estimation and Mapping of Wet and Dry Mercury Deposition Across Northeastern North America. Ecotoxicology 2005, 14, 53-70. [CrossRef] [PubMed]

50. Bell, J.N.B.; Treshow, M. Air Pollution and Plant Life, 2nd ed.; John Wiley \& Sons LTD: Hoboken, NJ, USA, 2002.

51. Qin, X.; Wang, X.; Shi, Y.; Yu, G.; Zhao, N.; Lin, Y.; Fu, Q.; Wang, D.; Xie, Z.; Deng, C.; et al. Characteristics of atmos-pheric mercury in a suburban area of east China: Sources, formation mechanisms, and regional transport. Atmos. Chem. Phys. 2019, 19, 5923-5940.

52. Smith-Downey, N.V.; Sunderland, E.; Jacob, D.J. Anthropogenic impacts on global storage and emissions of mercury from terrestrial soils: Insights from a new global model. J. Geophys. Res. Space Phys. 2010, 115. [CrossRef]

53. Rutter, A.P.; Schauer, J.J. The effect of temperature on the gas-particle partitioning of reactive mercury in atmospheric aerosols. Atmos. Environ. 2007, 41, 8647-8657. [CrossRef]

54. Isaac, M.; van Vuuren, D.P. Modeling global residential sector energy demand for heating and air conditioning in the context of climate change. Energ. Policy 2009, 37, 507-521.

55. FOREGS. Geochemical Atlas of Europe. Part 1-Background Information, Methodology and Maps; Salminen, R., Ed.; EuroGeoSurveys, Geological Survey of Finland: Espoo, Finland, 2005. 